Review

\title{
Liquid Biopsy as a Tool for the Characterisation and Early Detection of the Field Cancerization Effect in Patients with Oral Cavity Carcinoma
}

\author{
Elisabeth Pérez-Ruiz ${ }^{1, *,+} \mathbb{0}$, Vanesa Gutiérrez ${ }^{1,+}{ }^{1}$, Marta Muñoz ${ }^{1}$, Javier Oliver ${ }^{2} \mathbb{D}$, Marta Sánchez ${ }^{3}$, \\ Laura Gálvez-Carvajal ${ }^{1}$, Antonio Rueda-Domínguez ${ }^{1, *}$ and Isabel Barragán ${ }^{2,4}$ (D) \\ 1 Unidad de Gestión Clínica Intercentros de Oncología Médica, Oncology Department, Institute of Biomedical \\ Investigation of Malaga (IBIMA), Hospitales Universitarios Regional y Virgen de la Victoria, \\ 29010 Malaga, Spain; vanesa_gutierrez78@hotmail.com (V.G.); ayllon.m@gmail.com (M.M.); \\ lauragalvezcarvajal@hotmail.com (L.G.-C.) \\ 2 Researcher Unit, Unidad de Gestión Clínica Intercentros de Oncología Médica, Institute of Biomedical \\ Investigation of Malaga (IBIMA), Hospitales Universitarios Regional y Virgen de la Victoria, \\ 29010 Malaga, Spain; javiom@gmail.com (J.O.); isabel.barragan.mallofret@gmail.com or \\ isabel.barragan@ki.se (I.B.) \\ 3 Maxillofacial Surgery Department, Hospital Regional Universitario de Málaga, 29010 Málaga, Spain; \\ sanchezmarta11q@gmail.com \\ 4 Group of Pharmacoepigenetics, Department of Physiology and Pharmacology, Karolinska Institutet, \\ 17177 Stockholm, Sweden \\ * Correspondence: elisaonco@gmail.com (E.P.-R.); ruedadominguez@gmail.com (A.R.-D.) \\ + Equal contribution.
}

Citation: Pérez-Ruiz, E.; Gutiérrez, V.; Muñoz, M.; Oliver, J.; Sánchez, M.; Gálvez-Carvajal, L.; RuedaDomínguez, A.; Barragán, I. Liquid Biopsy as a Tool for the

Characterisation and Early Detection of the Field Cancerization Effect in Patients with Oral Cavity Carcinoma. Biomedicines 2021, 9, 1478. https:// doi.org/10.3390/biomedicines9101478

Academic Editor: Jan Plzak

Received: 26 August 2021

Accepted: 12 October 2021

Published: 15 October 202

Publisher's Note: MDPI stays neutral with regard to jurisdictional claims in published maps and institutional affiliations.

Copyright: (c) 2021 by the authors. Licensee MDPI, Basel, Switzerland. This article is an open access article distributed under the terms and conditions of the Creative Commons Attribution (CC BY) license (https:// creativecommons.org/licenses/by/ $4.0 /)$
Abstract: Oral squamous cell carcinoma (OSCC) constitutes approximately 25\% of all head and neck cancer, for which the consumption of tobacco and alcohol are the main associated risk factors. The field cancerization effect of OSCC is one of the main reasons for the poor survival rates associated with this disease. Despite some advances, its ccharacterization and early diagnosis continue to challenge modern oncology, and the goal of improving the prognosis remains to be achieved. Among new early diagnostic tools for OSCC that have been proposed, liquid biopsy appears to be an ideal candidate, as studies have shown that the analysis of blood and saliva provides promising data for the early detection of relapses or second tumours.

Keywords: oral cell carcinoma; field cancerization; liquid biopsy

\section{Oral Cavity Carcinoma}

Head and neck squamous cell carcinoma (HNSCC) is the sixth most common neoplasm worldwide [1,2]. Within this group of tumours, oral squamous cell carcinoma (OSCC) constitutes approximately $25 \%$ of all cases, for which the consumption of tobacco and alcohol are the main associated risk factors. Despite the ease of self-examination, this condition is usually diagnosed at locally advanced stages when regional lymph nodes have been affected. The main treatment option is surgical resection, combined with adjuvant radiotherapy or radiochemotherapy in patients at high risk of relapse [3,4]. Although multidisciplinary treatment is readily available, advanced OSCC has a poor prognosis, and only half of these patients will be disease-free at five years after surgery [5]. Moreover, this rate has not improved in the last decade despite the intensification of adjuvant treatments and preoperative chemotherapy [6], fundamentally due to a central biological aspect of this pathology: the field cancerization effect [7].

\section{Field Cancerization Effect in OSCC: Pathophysiology and Associated Problems}

The concept of field cancerization suggests that, in certain persons, the mucous membranes of the upper aerodigestive tract, when subjected to common carcinogens, are at 
greater risk of developing new carcinomas. Since this term was coined by Slaughter et al. in 1953 [7], it has been used to describe various types of pre-malignant disease, when a higher than expected prevalence of multiple local primary or secondary tumours is observed, accompanied by synchronous distant tumours. Slaughter studied the OSCCs obtained from 783 patients and detected multiple independent tumours in $11.2 \%$.

The monoclonal theory proposed to explain this field effect suggests that a single cell or a small group of cells (cluster) undergoes a malignant transformation, and that it is its dissemination (via saliva or intra-epithelial migration) that causes the appearance of multiple tumours. In contrast, the polyclonal theory is based on the premise that any transformation event is rare and that the existence of multiple lesions arises from the generalised migration of transformed cells throughout the aerodigestive tract $[8,9]$.

In recent years, molecular techniques have made it possible to extend our understanding of the relationships among these lesions, although the field remains controversial [10]. One of the challenges in OSCC is to define the degree of cancerization of a field effect, which involves differentiating between a mutant lineage (the presence of multiple mutations which, however, do not provoke carcinogenesis) and a cancerized lineage (characterized by mutations that in a suitable microenvironment result in tumour development) [11].

As observed above, the multifactorial aetiology and the characteristic field cancerization effect of this neoplasm are responsible for the appearance of multiple tumours in the oral cavity, the definitive diagnosis of which is made by solid biopsy of the tissue affected. The latter procedure, however, when conducted in an area that has been previously treated for the presence of a tumour, can generate significant comorbidity, is expensive and remains invasive. Furthermore, the solid biopsy approach has three important limitations: (1) it does not characterise the tumour heterogeneity in the tissue; (2) it may obtain insufficient material, or the suspicious injury may be in a dangerous area for re-biopsy, which would hamper or prevent complementary molecular study; and (3) the molecular profile of a relapse or progression of the disease might differ from that of the primary tumour, in which case it would be necessary to perform a re-biopsy, which for some patients would not be possible [12].

These considerations help explain why oral cavity neoplasms, their recurrences and/or second primary tumours are usually diagnosed late, which worsens the patient's prognosis. Therefore, to improve survival for patients with OSCC, the early detection and diagnosis of relapse and second tumour is vital.

\subsection{Liquid Biopsy}

In this respect, liquid biopsy has been proposed as a simple and effective tool, which does not generate comorbidity, is minimally invasive and provides valuable help in managing OSCC. This technique is based on the detection of tumour-related components in the bloodstream, saliva, cerebrospinal fluid or any other body fluid, and can identify circulating tumour cells (CTC) and circulating genetic material such as genomic DNA (gDNA), mitochondrial DNA (mtDNA), circulating tumour DNA (ctDNA), microRNA (miRNA) or exosomes.

Liquid biopsy is not only a highly accessible technique, it is also the ideal tool for the personalised study of tumour evolution, since it allows us to analyse the genetic variations that occur during the disease process, thus facilitating early diagnosis (as has been demonstrated with respect to other neoplasms) [13-16]. In the next sections, we will try to justify the potential role of liquid biopsy as a tool to characterize the effect of field cancerization in the OSCC.

\section{2. ctDNA in Oral Cavity Tumours}

Physiological and pathological processes in the body cause different forms of cell death and determine the types of material deposited in the body fluids. The determination of circulating cell-free DNA (cfDNA) in humans was the first step towards enabling liquid biopsy [17]. Subsequently, the detection of specific molecular aberrations of each 
tumour within the cfDNA made it possible to characterize a tumour-specific fraction of circulating DNA, termed the circulating tumour DNA (ctDNA) [18-20] which represents less than $1 \%$ of cfDNA and has significant potential as a biomarker in oncology [21,22]. The detection of ctDNA in cancer patients after treatment with curative intent indicates the presence of minimal residual disease, and is a prognostic marker of relapse for various tumours [23,24]. Most ctDNA studies of head and neck tumours have been carried out as part of broader investigations involving different types of tumours, such as breast, ovary, prostate, colorectal and lung. Lawrence MS et al. [24] describes the molecular profile of HNSCC, reporting TP53 (72\%), PIK3CA (21\%), FAT1 (23\%), and CDK2NA $(22 \%)$ as key mutations in these tumours. Lebofsky et al. [25] studied the concordance between ctDNA mutations and those observed in histological samples, and found that three patients with HNSCC presented $97 \%$ concordance between the ctDNA and the biopsies. The same study also found that the higher the tumour load, the higher the plasma concentration of ctDNA.

Many studies have been undertaken to consider the role of ctDNA in tumours of the upper aerodigestive tract. However, those focusing on the use of liquid biopsy in OSCC are few and heterogeneous. Table 1 summarizes the main studies of this question.

Among the studies published in the present century, of particular interest for our purposes are those by Nunes et al., Hamana et al. and Kakimoto et al. [26-28], all of which considered the level of microsatellite instability as a marker in patients with OSCC. Nunes et al. [26] analysed eight markers in tissue and serum and detected this alteration in $58 \%$ of cases (regardless of stage). Moreover, 17 patients presented the same alteration in plasma, leading the authors to conclude that this analysis could be used as a means of early diagnosis of OSCC. In contrast, Hamana et al. [27] and Kakimoto et al. [28], who each analysed nine markers of instability in the blood and tissue of patients before and after surgery, observed that those with allelic imbalance after surgery underwent relapse, a finding that suggests early biomarkers of OSCC relapse might be achieved. However, these studies were based on small samples of patients and their results have not been validated in prospective studies.

Shukla et al. [29] studied 150 patients with OSCC, using spectrometry to measure the quantity of cfDNA in plasma. These values were then compared with the cfDNA in 150 post-surgical OSCCs and in 90 pre-malignant lesions. No significant differences were observed between the groups of patients, and so the authors concluded that this analysis did not contribute to the early identification of pre-malignant lesions.

In an alternative approach, Wang et al. [30] explored the usefulness of ctDNA as a biomarker in plasma and saliva in 93 patients with HNSCC at different stages and in different anatomical locations. The results obtained showed that when a joint evaluation of plasma and saliva is performed, ctDNA is detected in $>90 \%$ of the patients. Moreover, the authors observed that sensitivity for the detection of ctDNA in saliva was dependent on the location of the primary tumour (the test was more effective in tumours of the oral cavity) and on the disease stage. In early stages, saliva appears to be a more sensitive predictor than plasma ( $100 \%$ vs. $70 \%$ respectively), while the latter is more sensitive in advanced stages ( $92 \%$ vs. $70 \%$ in saliva). In a related investigation, Mazurek et al. [31] analysed 200 patients with HNSCC, of whom 78 had oropharyngeal carcinoma, while the rest were non-oropharyngeal. This study detected higher concentrations of ctDNA in tumours of the oropharynx and in patients with a higher disease stage. Overall, $14 \%$ of these patients were Human Papilloma Virus (HPV)+. The virus was detected in $86 \%$ of plasma samples and $40 \%$ of saliva samples from the patients affected, while EGFR and KRAS were not detected in any case. The authors concluded that HPV cfDNA tests might facilitate early diagnosis.

More recently Perdomo et al. [32] used two approaches-targeted sequencing in five genes, and the sequencing of the entire coding region of the TP53 gene- to detect mutations in ctDNA and to determine the level of detection concordance between fluids and tissue in a cohort of patients that included 41 with OSCC. The results obtained demonstrated the potential value of detecting targeted mutations in the ctDNA of patients in early stages of HNSCC. However, the concordance in saliva was low; indeed, the analysis of TP53 
mutations in healthy individuals revealed the presence of pathogenic mutations, which should be taken into account in any subsequent design of ctDNA assays for early diagnosis.

Table 1. Studies of cell free DNA (cfDNA)/circulating tumour DNA (ctDNA) in blood and/or saliva samples from oral squamous cell carcinomas (OSCCs).

\begin{tabular}{|c|c|c|c|c|c|}
\hline Authors, Year & OSCCs $(n)$ & Other Tissue ( $n$ ) & Technique/Detection & Results & Discussion/Conclusion \\
\hline $\begin{array}{l}\text { Nunes et al. } \\
\text { (2001) [26] }\end{array}$ & 46 & 45 & $\begin{array}{l}\text { Eight microsatellite } \\
\text { markers in tissue and } \\
\text { serum (cfDNA) }\end{array}$ & $\begin{array}{l}58 \% \text { had microsatellite } \\
\text { alterations and } 17 \\
\text { patients had the same } \\
\text { profile in plasma. }\end{array}$ & Early detection. \\
\hline $\begin{array}{l}\text { Hamana et al. } \\
\text { (2005) [27] }\end{array}$ & 64 & None & $\begin{array}{c}\text { Nine microsatellite } \\
\text { markers in tissue and } \\
\text { serum (pre, } \\
\text { immediately } \\
\text { post-surgery and } 4 \\
\text { weeks after surgery }\end{array}$ & $\begin{array}{c}\text { Allelic imbalance } \\
\text { patterns in serum were } \\
\text { associated with the } \\
\text { presence of allelic } \\
\text { imbalance in paired } \\
\text { tumour tissue. } \\
\text { Patients with allelic } \\
\text { imbalance four weeks } \\
\text { after surgery developed } \\
\text { metastases }\end{array}$ & $\begin{array}{l}\text { Microsatellite analysis } \\
\text { could help assess the risk } \\
\text { of recurrence. }\end{array}$ \\
\hline $\begin{array}{l}\text { Kakimoto et al. } \\
\text { (2008) [28] }\end{array}$ & 20 & None & $\begin{array}{l}\text { Nine microsatellite } \\
\text { markers in tissue and } \\
\text { serum (one month } \\
\text { before and after } \\
\text { surgery) }\end{array}$ & $\begin{array}{l}\text { Allelic imbalance in } \\
\text { ctDNA was observed in } \\
\text { blood in } 90 \% \text { of patients }\end{array}$ & $\begin{array}{l}\text { Microsatellite analysis } \\
\text { could help assess the risk } \\
\text { of recurrence. }\end{array}$ \\
\hline $\begin{array}{l}\text { Shukla et al. } \\
\text { (2013) [29] }\end{array}$ & $\begin{array}{l}150 \text { OSCCs } 150 \\
\text { post-treatment } \\
\text { OSCCs }\end{array}$ & $\begin{array}{c}90 \text { potentially } \\
\text { malignant lesions }\end{array}$ & $\begin{array}{c}\text { Quantity of cfDNA in } \\
\text { plasma by } \\
\text { spectrophotometry }\end{array}$ & No differences & $\begin{array}{l}\text { Rich lymphatic drainage } \\
\text { of the oral mucosa } \\
\text { prevents it from entering } \\
\text { the bloodstream. }\end{array}$ \\
\hline $\begin{array}{c}\text { Wang et al. (2015) } \\
\text { [30] }\end{array}$ & 15 & 78 & $\begin{array}{c}\text { Pre and } \\
\text { post-treatment (9) } \\
\text { samples of blood and } \\
\text { saliva to detect } \\
\text { ctDNA and } \\
\text { mutations by } \\
\text { multiplex PCR. }\end{array}$ & $\begin{array}{l}\text { - ctDNA in blood and } \\
\text { saliva was found in } 96 \% \\
\text { of } 47 \text { patients. } \\
\text { - ctDNA was present in } \\
100 \% \text { of saliva and blood } \\
\text { specimens of OSCCs. } \\
\text { - After treatment, four } \\
\text { patients with ctDNA } \\
\text { underwent recurrence. }\end{array}$ & $\begin{array}{l}\text { Utility in monitoring. } \\
\text { Saliva provides a more } \\
\text { sensitive predictor of } \\
\text { early-stage disease than } \\
\text { plasma }\end{array}$ \\
\hline $\begin{array}{l}\text { Mazurek et al. } \\
\text { (2016) [31] }\end{array}$ & Unknown & 200 & $\begin{array}{l}H P V 16 / 18, K R A S \text { and } \\
\text { EGFR by q-PCR }\end{array}$ & $\begin{array}{c}14 \% \text { were HPV16+ } \\
\text { Neither EGFR and KRAS } \\
\text { were detected. } \\
H P V \text { was found in } 86 \% \text { of } \\
\text { plasma and } 40 \% \text { of saliva } \\
\text { specimens. }\end{array}$ & $\begin{array}{c}H P V \text { cfDNA could be } \\
\text { used for the early } \\
\text { detection and monitoring } \\
\text { of HPV+. }\end{array}$ \\
\hline
\end{tabular}

\section{Approaches:}

(a) Mutations in ctDNA of five genes

Perdomo et al. (2017) [32]

$41 \quad$ Other head and neck cancer identified in tissue and plasma

(b) TP53 mutation analysed in tissue, plasma and oral rinses. (a) 18 mutations in $42 \%$ of patients

(b) $36 \%, 3 \%$ and $26 \%$ of TP53 mutation (tissue, plasma and oral rinses)
Concordance of mutation detection was low between tumour tissue, oral rinses and plasma.

\begin{tabular}{|c|c|c|c|c|c|}
\hline $\begin{array}{l}\text { Shanmugam et al. } \\
\text { (2021) [33] }\end{array}$ & 121 & None & $\begin{array}{l}\text { Next generation } \\
\text { sequence (NGS) with } \\
\text { tissue and saliva } \\
\text { specimens (before } \\
\text { surgery) }\end{array}$ & $\begin{array}{c}\text { In } 95.87 \% \text { of cases, at } \\
\text { least one somatic variant } \\
\text { was identified. The most } \\
\text { prevalent mutated genes } \\
\text { were TP53, FAT1, } \\
\text { CDKN2A and NOTCH1 } \\
\text { (the same as in tumour } \\
\text { tissue). } \\
\text { Concordance between } \\
\text { mutations in tumour and } \\
\text { saliva was }>97 \% \text { but less } \\
\text { in early-stage disease. }\end{array}$ & $\begin{array}{l}\text { Sequencing platforms } \\
\text { could be used to screen } \\
\text { high-risk individuals, } \\
\text { facilitating early } \\
\text { detection and } \\
\text { monitoring. }\end{array}$ \\
\hline
\end{tabular}


Finally, a recent study by Shanmugam et al. [33] used massive sequencing techniques to analyse tissue and saliva samples from 121 pre-surgical patients with OSCC. Alterations were identified in more than $95 \%$ of these patients, and in more than $97 \%$ the alteration was present in saliva, although this concordance was lower in initial disease stages. The authors concluded that new massive sequencing techniques could enhance screening and the early detection of relapses.

In summary, the study of ctDNA, using either simple digital polymerase chain reaction (PCR) techniques or more complex ones based on next-generation sequencing, detects genetic alterations in the primary tumour, which can then be monitored and observed. However, as commented above, OSCCs are characterized by high levels of recurrence due to the field cancerization effect. As a result, performing peripheral blood monitoring (ctDNA) for molecular alterations in the primary tissue can obtain false negatives during follow-up if additional primary neoplasms appear. Therefore, further determinations are required, whether conducted singly or in conjunction with the determination and/or sequencing of ctDNA, in order to offset the field effect of the OSCC.

\subsection{Exosomal RNA}

As the cfDNA, miRNAs, either free in plasma or included in extracellular vesicles called exosomes, have been extensively studied in recent years. miRNAs are small noncoding RNAs with approximately 22 nucleotides that are responsible for regulating the expression of various genes at the post-transcriptional level. The expression of miRNA is altered in malignant tumours [34].

Many studies have been undertaken to clarify the role of miRNAs in OSCC. Although the use of different methodologies limits the reproducibility of the results obtained [35], some miRNAs associated with the diagnosis of OSCC have been described, and variations in their levels of expression have been described after surgery for this condition. Reported findings include the overexpression of mir 21 and mir31 and the downregulation of mir200a and mir125a [36] in the blood of patients with OSCC, in comparison with healthy subjects. A recent review describes the usefulness of these small RNAs as biomarkers for diagnosis; moreover, in vitro studies suggest they can also be used as therapeutic targets [37]. Furthermore, many of the miRNAs described are detected in saliva, which highlights the importance and accessibility of this fluid in the management of OSCC tumours [38-42]. A recent meta-analysis demonstrates the usefulness of determining the presence of miRNAs in blood or saliva as a tool for the early diagnosis of OSCC [35].

The extracellular vesicle population is comprised of different types of vesicles, according to their structure and content. These include microvesicles, exosomes and apoptotic bodies, each performing specific functions [43]. Many cell types, such as dendritic cells, B cells, T cells, mast cells, epithelial cells and tumour cells, can produce exosomes [44]. Unlike other microvesicles, exosomes do not initially bear nuclear DNA, but may contain coding and non-coding mitochondrial DNA, proteins, peptides, lipids and nucleic acids (messenger RNA, miRNA, circular RNA), with biological activity [45].

Exosomes are involved in different stages of tumour development, including carcinogenesis, growth and development (by transferring different types of molecules, exosomes modulate pathways and regulate gene activation). In addition, they play a significant role in angiogenesis, in neutralising the immune response (by transmitting suppressor signals to cells in the immune system or by inhibiting the activation of receptors of these cells) [46] in developing resistance to chemotherapeutic agents and, finally, in metastasis [47,48].

Due to their unique biogenesis and their ability to circulate freely throughout the body, exosomes have been proposed as potential biomarkers in a liquid biopsy [49]. Many studies have shown that the morphology and content of exosomes isolated from the saliva and blood of patients with OSCC differs greatly from those of healthy people, suggesting that exosomes might be used to diagnose OSCC at an early stage [50]. Furthermore, OSCC is composed of different cell types, each of which can secrete exosomes containing a unique set of miRNAs. For example, it has been shown that $m i R-200 c-3 p$ is capable of 
inducing invasive potential in non-invasive cells within a tumour mass in patients with OSCC [51]. To date, only a small fraction of the RNA contained in exosomes has been identified [52]. The miRNA described can play various roles in the development of OSCC, during growth (miR-142-3p), migration and invasion ( $m i R-200 c-3 p, m i R 3825 p, m i R-21)$, and in the development of metastases (miR-21-5p, miR-34a-5p, miR-29a-3p) [39,51,53,54].

Exosomes secreted by tumour cells are involved in angiogenesis and the development of metastasis under hypoxic conditions [48]. A miRNA expression profile of exosomes derived from hypoxic tumours revealed higher levels of miR-21, miR-205 and miR-148b compared to exosomes examined at a normal oxygen concentration. Furthermore, circulating levels of exosomal miRNA-21 were associated with the expression of HIF- $1 \alpha / H I F-2 \alpha$, T-stage and lymph node metastasis in patients with OSCC. These findings suggest that a hypoxic microenvironment may promote a prometastatic reaction, stimulating tumour cells to generate miRNA-21-rich exosomes that are delivered to normoxic cells [39]. As $m i R-21$, high levels of $m i R-483-5 p$ in serum from patients with oral cancer was correlated with tumour stage and lymph node metastasis $[55,56]$.

Recently, several studies have found that combining several miRNA, the specificity for the diagnosis of OSCC is significantly increased, highlighting miR-370-3p and miR-30a$5 p$ [57]. Other studies have shown that the plasma levels of miR-375-3p, miR-138-5p and miRNA-99-5 $p$ were associated with the clinical development of patients with OSCC [58].

In other studies, elevated levels of miR-24 in plasma have been associated with high sensitivity (AUC 0.82) in OSCC patients and with clinical stage. In vitro studies have been reported that the mechanism of action is through interaction with FBXW7 [59,60].

Tachibana et al. (2016) were able to identify 20 miRNA differentially expressed in tissue and plasma samples from patients with gingival squamous tumours using microarrays. It should be noted that miR-233 was found to be over-expressed in plasma but downregulated in the tissue, suggesting that it could be a local defence mechanism to inhibit local tumour growth [61].

\subsection{Exosomes in Blood}

Along with miRNAs, exosomes can also contain proteins, both inside and in their membranes. In the case of OSCC, some of the proteins contained in exosomes have been analysed, observing that they can promote tumorigenesis and regulate stromal cells.

An example is the secretion of exosomes containing epithelial growth factor receptor (EGFR), which can be heightened by the stimulation of its ligand (EGF). When vesicles are internalised by healthy epithelial cells around cancer cells, this produces an epitheliummesenchyme transition, by which normal cells are converted into spindle cells, thus promoting cell invasion and migration within the tumour medium [62].

A study analysed the exosomal surface proteins CD63 + and CAV1 + before and after surgery, in OSCC patients, and it was observed that low levels of CAV1 + exosomes before surgery were related to longer survival. Furthermore, a significantly lower expression of CD63 + exosomes was observed after surgery. This result seems to suggest that the tumour mass is responsible for the high levels of circulating exosomes detected in patients with this tumour type [56]. Therefore, the authors suggest that the monitoring of CD63 + exosome levels after tumour resection can be very useful for the clinical follow-up of patients with OSCC [56].

The use of immune checkpoint inhibitors of the PD1/PD-L1 pathway was a major advance in the treatment of recurrent and metastatic squamous cell carcinomas of the head and neck [63]. Exosomes can transport PD-L1, which affects the modulation of the tumour microenvironment and the disease progression. In this respect, Theodoraki et al. isolated exosomes from the plasma of 40 patients with HNSCC, observing that these exosomes carried biologically active PD-L1, which was correlated with the tumour stage and with lymph node involvement [64]. 


\subsection{Exosomes in Saliva}

The determination of exosomes in saliva is simple and non-invasive. Saliva contains less protein than blood, which greatly simplifies the identification and quantification of exosomes. Moreover, it can be stored at $4{ }^{\circ} \mathrm{C}$ (without the need for freezing at $-80{ }^{\circ} \mathrm{C}$ ), which facilitates storage and conservation [65].

Recently, a signature of miRNA from saliva exosomes of OSCC patients has been reported, and it was observed that the miRNA $m i R-320-3 p$ and $m i R-517 b-3 p$ and $m i R-320-3 p$ were significantly represented and specified with an AUC of 0.87 [66].

Previously, massive expression studies in direct saliva samples (without isolating exosomes) that included patients and healthy controls showed that several miRNAs have been found with low expression, including miR-125a, miR-147, miR-136, miR-148a, miR-200, miR-323-5p, miR-668 miR-503, miR-632, miR-646, miR-877, and miR-1250; on the other hand, two miRNAs (miR-24 and miR-27b) were up-regulated [67,68].

In 2011, two types of salivary exosomes were described, differing mainly in their size and protein composition. Type I exosomes are larger and denser to electrons, while type II are more similar to those present in other body fluids [69]. Salivary exosomes participate in the catabolism of biopeptides and play an important role in the local immune response of the oral cavity.

In 2016, an in vitro study by Ogawa et al. showed that the content of salivary exosomes could be transferred horizontally to other cells, modulating the gene expression of the receptors and increasing their invasive and migratory capacity [70].

Langevin et al. used mass sequencing to differentiate the miRNAs from tumour cells from those of healthy epithelial cells. These authors observed that many miRNAs were common to the exosomes of both healthy and cancerous cells. However, significantly higher concentrations of $m i R-486-5 p, m i R-486-3 p$ and $m i R-10 b-5 p$ were detected in the tumour cells than in the control group. This finding provided important information on tumour biology and generated a novel set of biomarkers to discriminate between OSCC and potentially malignant oral lesions, which is crucially important to the goal of preventing the field effect of these tumours [71].

Finally, Zlotogorski-Hurvitz et al. detected morphological and molecular differences in the salivary exosomes of patients with OSCC with respect to healthy patients, and suggested that this feature could be employed as a screening measure for high-risk patients. These authors analysed the expression of three exosomal markers (CD9, CD81 and CD63) and found a higher mean concentration of CD63 exosomes and a lower one of CD9 and CD81 exosomes between cancer patients and healthy individuals, although significant statistical differences were only observed with respect to CD81 exosomes [50].

\subsection{Circulating Tumour Cells (CTCs)}

CTCs are released by the primary tumour or by metastatic lesions into the bloodstream, and therefore share most of their mutational profile with that of the tumour clones present in the primary tumour. CTCs may circulate alone or in groups, the latter having greater metastatic potential [72]. One of the characteristics of CTCs is their low ratio, approximately 1 CTC per $10^{7}$ white cells per millilitre of blood in metastatic patients. Various techniques can be used to determine the quantity of CTCs present, but the CellSearch ${ }^{\circledR}$ platform is the only one approved for prognostic use in patients with breast, prostate or colorectal cancer [73].

Most studies of OSCC have focused on validating CTCs as prognostic biomarkers and predictors of relapse by reference to CTC levels or their genomic characterisation [74,75].

A 2014 study reported data on the prognostic value of the CTC count in 110 patients with different stages of OSCC, the correlation of this value with clinical and pathological parameters, and rates of relapse or death. The authors also analysed the presence of disseminated tumour cells (DTCs) in the bone marrow of the iliac crest. The recorded presence of CTCs was $12.5 \%$ with a range of $1-14$ CTCs $/ 7.5 \mathrm{~mL}$. Detection was significantly correlated with tumour size and with the presence of distal metastases, but no statistically 
significant association was found with overall survival or with time to relapse or death, probably due to the small sample size [76]. Although no significant correlation was found between the detection of CTCs and DTCs, their joint presence was significantly associated with relapse-free survival time.

A later study analysed the prognostic value of CTCs in 40 patients with OSCC, either locally advanced $(38 \%)$ or oropharyngeal $(63 \%)$. All patients were treated with induction therapy, with docetaxel, cisplatin and fluorouracil, surgery, and postoperative adjuvant radiation therapy. At baseline, CTCs were detected in $80 \%$ of the patients; at the completion of treatment, 3\% had no CTCs. Higher CTC levels were associated with a higher risk of recurrence during treatment and with lower overall survival. Postsurgical CTC levels were elevated (although they decreased after radiotherapy), but were not associated with a negative prognostic impact [74].

In addition to the CTC count, the molecular characterisation of CTCs in OSCCs has been addressed using EGFR, podoplanin or EpCAM, among other parameters. In this respect, Oliveira-Costa et al. [77] analysed the gene expression profile of a series of oral cavity tumours, seeking to identify biomarkers by searching for genes whose expression is increased or decreased during their natural history. A total of 879 transcripts increased or decreased significantly from stage T1 to T4. Of these, six (PD-L1, HOXB9, DHDH, BLNK, ZNF813 and IL6ST) were validated by qRT-PCR in tissue samples. Consideration of four of these markers in CTCs revealed an increase in the expression of PD-L1, HOXB9 and ZNF813 and a significant decrease in that of BLNK. In view of these findings, the authors suggested that patients with CTC PD-L1+ might benefit from anti-PD-L1 therapy.

Strati et al. conducted a prospective study of a cohort of patients with locally advanced carcinoma of the head and neck, and reported that the evaluation of PD-L1-overexpressing CTCs in liquid biopsies is feasible and may provide significant prognostic information. These considerations have significant implications for patients being treated with PD1 inhibitors [78].

CTC analysis is a developing technique in the field of HNSCC in general and in that of OSCC in particular. However, a factor of crucial importance in any future clinical implementation is the need to improve the sensitivity of the techniques used to quantify and characterise the presence of CTCs.

In Table 2, we summarise the potential role of different liquid biopsy technical approaches for the diagnosis and prognosis of OSCC.

Table 2. Liquid biopsy technical approaches for oral squamous cell carcinoma (OSCC) diagnosis and prognosis.

\begin{tabular}{ccc}
\hline Liquid Biopsy Techniques & Diagnosis/Prognosis & References \\
\hline ctDNA & Diagnosis $>$ Prognosis & {$[26,32,33]$} \\
\hline miRNA & Diagnosis $>$ prognosis & {$[35,36]$} \\
\hline Exosomes & Diagnosis & {$[50,71]$} \\
\hline CTC & Prognosis & {$[74,75]$} \\
\hline
\end{tabular}

ctDNA: circulating tumoral DNA; miRNA: microRNA; CTC: circulating tumours cells.

\section{Conclusions}

The field cancerization effect of OSCC is one of the main reasons for the poor survival rates associated with this disease. Despite some advances, its characterisation and early diagnosis continue to challenge modern oncology, and the goal of improving the prognosis remains to be achieved.

Among new early diagnostic tools for OSCC that have been proposed, liquid biopsy appears to be an ideal candidate, as studies have shown that the analysis of blood and saliva provides promising data for the early detection of relapses or second tumours.

Determining the presence of ctDNA or of specific mutations of primary tumours via the analysis of blood or saliva may play a useful role in screening high-risk patients, 
especially if this analysis is conducted via massive sequencing techniques enabling a broadbased characterisation. A good example of such utility that has been adopted to clinical practice is the assessment and tracking of cfHPV DNA in HPV related oropharyngeal cancer, both at diagnosis and as treatment efficacy monitoring. However, given the possibility of further primary tumours or of field effect tumours with molecular alterations differing from those of the primary tumour, it remains necessary to study other liquid biopsy components in order to enhance the characterisation of tumourigenesis in patients with OSCC.

The study of CTCs remains open and the reliable early detection of tumour recurrence is a goal that has yet to be met, as the sensitivity and reproducibility of the techniques described remain far from optimal. Nevertheless, we believe CTCs could play a significant role in characterising recurrent/metastatic OSCC, as has been demonstrated for other tumours.

Finally, the study of free miRNAs, whether circulating or incorporated in exosomes, as well as the study and characterisation of exosomes themselves, have shown promising results. Although the results of different studies have not been replicated, recent improvements in sequencing have facilitated massive data analyses that have yielded a wealth of new information on the role of miRNAs and exosomes in OSCCs.

Author Contributions: Conceptualization, E.P.-R., I.B., A.R.-D.; methodology, E.P.-R., V.G., M.M.; data curation, E.P.-R., V.G., M.M., J.O., M.S., L.G.-C., I.B. and A.R.-D.; writing-original draft preparation, E.P.-R., V.G. and A.R.-D.; writing—review and editing, E.P.-R., V.G., M.M., J.O., M.S., L.G.-C., I.B. and A.R.-D.; supervision A.R.-D., I.B. and E.P.-R. All authors have read and agreed to the published version of the manuscript.

Funding: E.P.-R. has received a grant from The Spanish Society of Medical Oncology (SEOM). IB has received funding (project SA 0263/2017, Nicolás Monardes Program) from the Consejería de Salud y Familias, Junta de Andalucía, Spain.

Institutional Review Board Statement: Not applicable.

Informed Consent Statement: Not applicable.

Data Availability Statement: Not applicable.

Conflicts of Interest: The authors declare no conflict of interest.

\section{References}

1. Argiris, A.; Karamouzis, M.V.; Raben, D.; Ferris, R.L. Head and neck cancer. Lancet 2008, 371, 1695-1709. [CrossRef]

2. González-Santiago, S.; Cajal, T.R.; Aguirre, E.; Alés-Martínez, J.E.; Andrés, R.; Balmaña, J.; Graña, B.; Herrero, A.; Llort, G.; González-Del-Alba, A. SEOM clinical guidelines for the treatment of head and neck cancer (2019). Clin. Transl. Oncol. 2020, 22, 193-200. [CrossRef]

3. Bernier, J.; Domenge, C.; Ozsahin, M.; Matuszewska, K.; Lefèbvre, J.-L.; Greiner, R.H.; Giralt, J.; Maingon, P.; Rolland, F.; Bolla, M.; et al. Postoperative irradiation with or without concomitant chemotherapy for locally advanced head and neck cancer. N. Engl. J. Med. 2004, 350, 1945-1952. [CrossRef] [PubMed]

4. Gan, S.J.; Dahlstrom, K.R.; Peck, B.W.; Caywood, W.; Li, G.; Wei, Q.; Zafereo, M.E.; Sturgis, E.M. Incidence and pattern of second primary malignancies in patients with index oropharyngeal cancers versus index nor opharyngeal head and neck cancers. Cancer 2013, 119, 2593-2601. [CrossRef]

5. Zhong, L.P.; Zhang, C.P.; Ren, G.X.; Guo, W.; William, W.N., Jr.; Sun, J.; Zhu, H.G.; Tu, W.Y.; Li, J.; Cai, Y.L.; et al. Randomized phase III trial of induction chemotherapy with docetaxel, cisplatin and fluoracil followed by surgery versus up-front surgery in locally advanced resectable oral squamous cell carcinoma. J. Clin. Oncol. 2013, 31, 744-751. [CrossRef]

6. Blanchard, P.; Bourhis, J.; Lacas, B.; Posner, M.R.; Vermorken, J.B.; Hernandez, J.J.C.; Bourredjem, A.; Calais, G.; Paccagnella, A.; Hitt, R.; et al. Taxane-cisplatin-fluorouracil as induction chemotherapy in locally advanced head and neck cancers: An individual patient data meta-analysis of the meta-analysis of chemotherapy in head and neck cancer group. J. Clin. Oncol. 2013, 31, 2854-2860. [CrossRef] [PubMed]

7. Slaughter, D.P.; Southwick, H.W.; Smejkal, W. Field cancerization in oral stratified squamous epithelium: Clinical implication of multicentric origin. Cancer 1953, 6, 963-968. [CrossRef]

8. Van Oijen, M.G.; Slootweg, P.J. Oral field cancerization: Carcinogen induced independent events or micrometastatic deposits? Cancer Epidemiol. Prev. Biomark. 2000, 9, 249-256.

9. Van Oijen, M.G.; Gilsing, M.M.A.; Rijksen, G.; Hordijk, G.J.; Slootweg, P.J. Increased number of proliferating cells in oral epithelium from smokers and ex-smokers. Oral Oncol. 1998, 34, 297-303. [CrossRef] 
10. Mohan, M.; Jagannathan, N. Oral field cancerization: An update on current concepts. Oncol. Rev. 2014, 8, 244.

11. Curtius, K.; Wright, N.A.; Graham, T.A. An evolutionary perspective on field cancerization. Nat. Rev. Cancer 2018, 18, 19-32. [CrossRef]

12. Gerlinger, M.; Rowan, A.J.; Horswell, S.; Larkin, J.; Endesfelder, D.; Gronroos, E.; Martinez, P.; Matthews, N.; Stewart, A.; Tarpey, P.; et al. Intratumor heterogeneity and branched evolution revealed by multiregion sequencing. N. Engl. J. Med. 2012, 366, 883-892. [CrossRef]

13. Misale, S.; Yaeger, R.; Hobor, S.; Scala, E.; Janakiraman, M.; Liska, D.; Valtorta, E.; Schiavo, R.; Buscarino, M.; Siravegna, G.; et al. Emergence of KRAS mutations and acquired resistance to anti-EGFR therapy in colorectal cancer. Nature 2012, 486, 532-536. [CrossRef]

14. Diaz, L.A., Jr.; Williams, R.T.; Wu, J.; Kinde, I.; Hecht, J.R.; Berlin, J.; Allen, B.; Bozic, I.; Reiter, J.G.; Nowak, M.A.; et al. The molecular evolution of acquired resistance to targeted EGFR blockade in colorectal cancers. Nature 2012, 486, 537-540. [CrossRef]

15. Wu, Y.-L.; Tong, R.-Z.; Zhang, Y.; Hu, B.-B.; Zheng, K.; Ding, Z.-Y.; Peng, F.; Gong, Y.-L.; Liu, Y.-M.; Lu, Y. Conventional real-time PCR-based detection of T790M using tumor tissue or blood in patients with EGFR TKI-resistant NSCLC. OncoTargets Ther. 2017, 10, 3307-3312. [CrossRef]

16. Vidal, J.; Muinelo, L.; Dalmases, A.; Jones, F.; Edelstein, D.; Iglesias, M.; Orrillo, M.; Abalo, A.; Rodríguez, C.; Brozos, E.; et al. Plasma ctDNA RAS mutation analysis for the diagnosis and treatment monitoring of metastatic colorectal cancer patients. Ann. Oncol. 2017, 28, 1325-1332. [CrossRef]

17. Mandel, P. [Nuclear Acids In Human Blood Plasma]. CR Seances Soc. Biol. Fil. 1948, 142, 241-243.

18. Diehl, F.; Schmidt, K.; Choti, M.A.; Romans, K.; Goodman, S.; Li, M.; Thornton, K.; Agrawal, N.; Sokoll, L.; Szabo, S.A.; et al. Circulating mutant DNA to assess tumor dynamics. Nat. Med. 2008, 14, 985-990. [CrossRef]

19. Chan, K.A.; Jiang, P.; Zheng, Y.W.; Liao, G.J.; Sun, H.; Wong, J.; Siu, S.S.N.; Chan, W.C.; Chan, S.L.; Chan, A.T.; et al. Cancer genome scanning in plasma: Detection of tu-mor-associated copy number aberrations, single-nucleotide variants, and tumoral heterogeneity by massively parallel se-quencing. Clin. Chem. 2013, 59, 211-224. Available online: https:// pubmed.ncbi.nlm.nih. gov /23065472/ (accessed on 24 June 2021). [CrossRef]

20. Bidard, F.C.; Weigelt, B.; Reis-Filho, J.S. Going with the flow: From circulating tumor cells to DNA. Sci. Transl. Med. 2013, 5, 207ps14. Available online: https:/ / pubmed.ncbi.nlm.nih.gov/24132635/ (accessed on 24 June 2021). [CrossRef]

21. Crowley, E.; Di Nicolantonio, F.; Loupakis, F.; Bardelli, A. Liquid biopsy: Monitoring cancer-genetics in the blood. Nat. Rev. Clin. Oncol. 2013, 10, 472-484. Available online: https: / / pubmed.ncbi.nlm.nih.gov/23836314/ (accessed on 24 June 2021). [CrossRef]

22. Diaz, L.A., Jr.; Bardelli, A. Liquid biopsies: Genotyping circulating tumor DNA. J. Clin. Oncol. 2014, 32, 579-586. Available online: https: / / pubmed.ncbi.nlm.nih.gov/24449238/ (accessed on 24 June 2021). [CrossRef]

23. Schwarzenbach, H.; Hoon, D.S.B.; Pantel, K. Cell-free nucleic acids as biomarkers in cancer patients. Nat. Rev. Cancer 2011, 11, 426-437. Available online: https:/ / pubmed.ncbi.nlm.nih.gov/21562580/ (accessed on 24 June 2021). [CrossRef]

24. The Cancer Genome Atlas Network. Comprehensive genomic characterization of head and neck squamous cell carcinomas. Nature 2015, 517, 576-582. Available online: https:/ / pubmed.ncbi.nlm.nih.gov/25631445/ (accessed on 24 June 2021). [CrossRef]

25. Lebofsky, R.; Decraene, C.; Bernard, V.; Kamal, M.; Blin, A.; Leroy, Q.; Frio, T.R.; Pierron, G.; Callens, C.; Bieche, I.; et al. Circulating tumor DNA as a non-invasive substitute to metastasis biopsy for tumor genotyping and personalized medicine in a prospective trial across all tumor types. Mol. Oncol. 2015, 9, 783-790. [CrossRef]

26. Noronha Nunes, D.; Paulo Kowalski, L.; Simpson, A.J. Circulating tumor-derived DNA may permit the early diagnosis of head and neck squamous cell carcinomas. Int. J. Cancer 2001, 92, 214-219. [CrossRef]

27. Hamana, K.; Uzawa, K.; Ogawara, K.; Shiiba, M.; Bukawa, H.; Yokoe, H.; Tanzawa, H. Monitoring of circulating tumour-associated DNA as a prognostic tool for oral squamous cell carcinoma. Br. J. Cancer 2005, 92, 2181-2184. [CrossRef]

28. Kakimoto, Y.; Yamamoto, N.; Shibahara, T. Microsatellite analysis of serum DNA in patients with oral squamous cell carcinoma. Oncol. Rep. 1994, 20, 1195-1200. [CrossRef]

29. Shukla, D.; Kale, A.D.; Hallikerimath, S.; Yerramalla, V.; Subbiah, V. Can quantifying free-circulating DNA be a diagnostic and prognostic marker in oral epithelial dysplasia and oral squamous cell carcinoma? J. Oral Maxillofac. Surg. 2013, 71, 414-418. [CrossRef]

30. Wang, Y.; Springer, S.; Mulvey, C.L.; Silliman, N.; Schaefer, J.; Sausen, M.; James, N.; Rettig, E.M.; Guo, T.; Pickering, C.; et al. Detection of somatic mutations and HPV in the saliva and plasma of patients with head and neck squamous cell carcinomas. Sci. Transl. Med. 2015, 7, 293ra104. [CrossRef]

31. Mazurek, A.M.; Rutkowski, T.; Fiszer-Kierzkowska, A.; Małusecka, E.; Składowski, K. Assessment of the total cfDNA and HPV16/18 detection in plasma samples of head and neck squamous cell carcinoma patients. Oral Oncol. 2016, 54, 36-41. [CrossRef]

32. Perdomo, S.; Avogbe, P.H.; Foll, M.; Abedi-Ardekani, B.; Facciolla, V.L.; Anantharaman, D.; Chopard, P.; Le Calvez-Kelm, F.; Vilensky, M.; Polesel, J.; et al. Circulating tumor DNA detection in head and neck cancer: Evaluation of two different detection approaches. Oncotarget 2017, 8, 72621-72632. [CrossRef]

33. Shanmugam, A.; Hariharan, A.K.; Hasina, R.; Nair, J.R.; Katragadda, S.; Irusappan, S.; Ravichandran, A.; Veeramachaneni, V.; Bettadapura, R.; Bhati, M.; et al. Ultrasensitive detection of tumor-specific mutations in saliva of patients with oral cavity squamous cell carcinoma. Cancer 2021, 127, 1576-1589. [CrossRef] 
34. Mazumder, S.; Datta, S.; Ray, J.G.; Chaudhuri, K.; Chatterjee, R. Liquid biopsy: miRNA as a potential biomarker in oral cancer. Cancer Epidemiol. 2019, 58, 137-145. Available online: https://pubmed.ncbi.nlm.nih.gov/30579238/ (accessed on 24 June 2021). [CrossRef]

35. Rapado-González, O.; Martínez-Reglero, C.; Salgado-Barreira, A.; López-López, R.; Suárez-Cunqueiro, M.; Muinelo-Romay, L. miRNAs in liquid biopsy for oral squamous cell carcinoma diagnosis: Systematic review and meta-analysis. Oral Oncol. 2019, 99, 104465. [CrossRef]

36. Menini, M.; De Giovanni, E.; Bagnasco, F.; Delucchi, F.; Pera, F.; Baldi, D.; Pesce, P. Salivary micro-RNA and oral squamous cell carcinoma: A systematic review. J. Pers. Med. 2021, 11, 101. [CrossRef]

37. Rapado-González, Ó.; López-López, R.; López-Cedrún, J.L.; Triana-Martínez, G.; Muinelo-Romay, L.; Suárez-Cunqueiro, M.M. Cell-free microRNAs as potential oral cancer biomarkers: From diagnosis to therapy. Cells 2019, 8, 1653. [CrossRef]

38. Rabinowits, G.; Bowden, M.; Flores, L.M.; Verselis, S.; Vergara, V.; Jo, V.Y.; Chau, N.; Lorch, J.; Hammerman, P.S.; Thomas, T.; et al. Comparative analysis of microRNA expression among benign and malignant tongue tissue and plasma of patients with tongue cancer. Front. Oncol. 2017, 7, 191. [CrossRef]

39. Li, L.; Li, C.; Wang, S.; Wang, Z.; Jiang, J.; Wang, W.; Li, X.; Chen, J.; Liu, K.; Li, C.; et al. Exosomes derived from hypoxic oral squamous cell carcinoma cells deliver miR-21 to normoxic cells to elicit a prometastatic phenotype. Cancer Res. 2016, 76, 1770-1780. [CrossRef]

40. Shah, K.; Patel, S.; Modi, B.; Shah, F.; Rawal, R. Uncovering the potential of CD44v/SYNE1/miR34a axis in salivary fluids of oral cancer patients. J. Oral Pathol. Med. 2018, 47, 345-352. [CrossRef]

41. He, L.; Ping, F.; Fan, Z.; Zhang, C.; Deng, M.; Cheng, B.; Xia, J. Salivary exosomal miR-24-3p serves as a potential detective biomarker for oral squamous cell carcinoma screening. Biomed. Pharmacother. 2020, 121, 109553. [CrossRef] [PubMed]

42. Momen-Heravi, F.; Trachtenberg, A.; Kuo, W.; Cheng, Y. Genomewide study of salivary microRNAs for detection of oral cancer. J. Dent. Res. 2014, 93, 86S-93S. [CrossRef]

43. György, B.; Szabó, T.G.; Pásztói, M.; Pál, Z.; Misják, P.; Aradi, B.; László, V.; Pállinger, E.; Pap, E.; Kittel, A.; et al. Membrane vesicles, current state-of-the-art: Emerging role of extracellular vesicles. Cell. Mol. Life Sci. 2011, 68, 2667-2688. Available online: https: / / pubmed.ncbi.nlm.nih.gov/21560073/ (accessed on 24 June 2021). [CrossRef]

44. O'Loughlin, A.J.; Woffindale, C.A.; Wood, M.J.A. Exosomes and the emerging field of exosome-based gene therapy. Curr. Gene Ther. 2012, 12, 262-274. [CrossRef] [PubMed]

45. Sansone, P.; Savini, C.; Kurelac, I.; Chang, Q.; Amato, L.B.; Strillacci, A.; Stepanova, A.; Iommarini, L.; Mastroleo, C.; Daly, L.; et al. Packaging and transfer of mitochondrial DNA via exosomes regulate escape from dormancy in hormonal therapy-resistant breast cancer. Proc. Natl. Acad. Sci. USA 2017, 114, E9066-E9075. [CrossRef] [PubMed]

46. Iero, M.; Valenti, R.; Huber, V.; Filipazzi, P.; Parmiani, G.; Fais, S.; Rivoltini, L. Tumour-released exosomes and their implications in cancer immunity. Cell Death Differ. 2008, 15, 80-88. Available online: https:// pubmed.ncbi.nlm.nih.gov/17932500/ (accessed on 24 June 2021). [CrossRef]

47. Guo, W.; Gao, Y.; Li, N.; Shao, F.; Wang, C.; Wang, P.; Yang, Z.; Li, R.; He, J. Exosomes: New players in cancer. Oncol. Rep. 2017, 38, 665-675. Available online: https://pubmed.ncbi.nlm.nih.gov/28627679/ (accessed on 24 June 2021). [CrossRef]

48. Park, J.E.; Tan, H.S.; Datta, A.; Lai, R.C.; Zhang, H.; Meng, W.; Lim, S.K.; Sze, S.K. Hypoxic tumor cell modulates its microenvironment to enhance angiogenic and metastatic potential by secretion of proteins and exosomes. Mol. Cell. Proteom. 2010, 9 , 1085-1099. [CrossRef]

49. Whiteside, T.L. The potential of tumor-derived exosomes for noninvasive cancer monitoring: An update. Expert Rev. Mol. Diagn. 2018, 18, 1029-1040. Available online: https: / / pubmed.ncbi.nlm.nih.gov/30406709/ (accessed on 24 June 2021). [CrossRef]

50. Zlotogorski-Hurvitz, A.; Dayan, D.; Chaushu, G.; Salo, T.; Vered, M. Morphological and molecular features of oral fluid-derived exosomes: Oral cancer patients versus healthy individuals. J. Cancer Res. Clin. Oncol. 2016, 142, 101-110. [CrossRef]

51. Kawakubo-Yasukochi, T.; Morioka, M.; Hazekawa, M.; Yasukochi, A.; Nishinakagawa, T.; Ono, K.; Kawano, S.; Nakamura, S.; Nakashima, M. miR-200c-3p spreads in-vasive capacity in human oral squamous cell carcinoma microenvironment. Mol. Carcinog. 2018, 57, 295-302. Available online: https://pubmed.ncbi.nlm.nih.gov/28981169/ (accessed on 24 June 2021). [CrossRef] [PubMed]

52. Abels, E.R.; Breakefield, X.O. Introduction to extracellular vesicles: Biogenesis, RNA cargo selection, content, release, and uptake. Cell. Mol. Neurobiol. 2016, 36, 301-312. [CrossRef] [PubMed]

53. Dickman, C.T.; Lawson, J.; Jabalee, J.; MacLellan, S.A.; LePard, N.E.; Bennewith, K.L.; Garnis, C. Selective extracellular vesicle exclusion of miR-142-3p by oral cancer cells promotes both internal and extracellular malignant phenotypes. Oncotarget 2017, 8 , 15252-15266. [CrossRef]

54. Sun, L.P.; Xu, K.; Cui, J.; Yuan, D.Y.; Zou, B.; Li, J.; Liu, J.L.; Li, K.Y.; Meng, Z.; Zhang, B. Cancer-associated fibroblast-derived exosomal miR-382-5p promotes the migration and invasion of oral squamous cell carcinoma. Oncol. Rep. 2019, 42, 1319-1328. Available online: https:/ / pubmed.ncbi.nlm.nih.gov/31364748/ (accessed on 24 June 2021). [CrossRef] [PubMed]

55. Xu, H.; Yang, Y.; Zhao, H.; Yang, X.; Luo, Y.; Ren, Y.; Liu, W.; Li, N. Serum miR-483-5p: A novel diagnostic and prognostic bi-omarker for patients with oral squamous cell carcinoma. Tumour Biol. 2016, 37, 447-453. [CrossRef] [PubMed]

56. Zorrilla, S.R.; Pérez-Sayans, M.; Fais, S.; Logozzi, M.; Torreira, M.G.; García, A.G. A pilot clinical study on the prognostic relevance of plasmatic exosome levels in oral squamous cell carcinoma patients. Cancers 2019, 11, 429. Available online: https:/ / pubmed.ncbi.nlm.nih.gov/30917536/ (accessed on 24 June 2021). [CrossRef] [PubMed] 
57. Pedersen, N.J.; Jensen, D.H.; Lelkaitis, G.; Kiss, K.; Charabi, B.W.; Ullum, H.; Specht, L.; Schmidt, A.Y.; Nielsen, F.C.; von Buchwald, C. MicroRNA-based classifiers for diagnosis of oral cavity squamous cell carcinoma in tissue and plasma. Oral Oncol. 2018, 83, 46-52. [CrossRef] [PubMed]

58. Lu, Z.; He, Q.; Liang, J.; Li, W.; Su, Q.; Chen, Z.; Wan, Q.; Zhou, X.; Cao, L.; Sun, J.; et al. miR-31- 5p is a potential circulating biomarker and therapeutic target for oral cancer. Mol. Ther.-Nucleic Acids 2019, 16, 471-480. [CrossRef]

59. Lin, S.-C.; Liu, C.-J.; Lin, J.-A.; Chiang, W.-F.; Hung, P.-S.; Chang, K.-W. miR-24 up-regulation in oral carcinoma: Positive association from clinical and in vitro analysis. Oral Oncol. 2010, 46, 204-208. [CrossRef]

60. Zhao, J.; Hu, C.; Chi, J.; Li, J.; Peng, C.; Yun, X.; Li, D.; Yu, Y.; Li, Y.; Gao, M.; et al. miR-24 promotes the proliferation, migration and invasion in human tongue squamous cell carcinoma by targeting FBXW7. Oncol. Rep. 2016, 36, 1143-1149. [CrossRef]

61. Tachibana, H.; Sho, R.; Takeda, Y.; Zhang, X.; Yoshida, Y.; Narimatsu, H.; Otani, K.; Ishikawa, S.; Fukao, A.; Asao, H.; et al. Cir-culating miR-223 in oral cancer: Its potential as a novel diagnostic biomarker and therapeutic target. PLoS ONE 2016, 11, e0159693. [CrossRef]

62. Aiello, N.; Maddipati, R.; Norgard, R.J.; Balli, D.; Li, J.; Yuan, S.; Yamazoe, T.; Black, T.; Sahmoud, A.; Furth, E.E.; et al. EMT subtype influences epithelial plasticity and mode of cell migration. Dev. Cell 2018, 45, 681-695.e4. [CrossRef] [PubMed]

63. Ferris, R.L. Immunology and immunotherapy of head and neck cancer. J. Clin. Oncol. 2015, 33, 3293-3304. Available online: https:/ / pubmed.ncbi.nlm.nih.gov/26351330/ (accessed on 24 June 2021). [CrossRef] [PubMed]

64. Theodoraki, M.N.; Yerneni, S.S.; Hoffmann, T.K.; Gooding, W.E.; Whiteside, T.L. Clinical significance of PD-L1 p exosomes in plasma of head and neck cancer patients. Clin. Cancer Res. 2018, 24, 896-905. Available online: https://pubmed.ncbi.nlm.nih. gov /29233903/ (accessed on 24 June 2021). [CrossRef]

65. Schulz, B.L.; Cooper-White, J.; Punyadeera, C.K. Saliva proteome research: Current status and future outlook. Crit. Rev. Biotechnol. 2013, 33, 246-259. Available online: https:/ / pubmed.ncbi.nlm.nih.gov/22612344/ (accessed on 24 June 2021). [CrossRef]

66. Gai, C.; Camussi, F.; Broccoletti, R.; Gambino, A.; Cabras, M.; Molinaro, L.; Carossa, S.; Camussi, G.; Arduino, P.G. Salivary extracellular vesicle-associated miRNAs as potential biomarkers in oral squamous cell carcinoma. BMC Cancer 2018, 18, 1-11. [CrossRef]

67. Yang, Y.; Li, Y.-X.; Yang, X.; Jiang, L.; Zhou, Z.-J.; Zhu, Y.-Q. Progress risk assessment of oral premalignant lesions with saliva miRNA analysis. BMC Cancer 2013, 13, 129. [CrossRef]

68. Park, N.J.; Zhou, H.; Elashoff, D.; Henson, B.S.; Kastratovic, D.A.; Abemayor, E.; Wong, D.T. Salivary microRNA: Discovery, characterization, and clinical utility for oral cancer detection. Clin. Cancer Res. 2009, 15, 5473-5477. [CrossRef] [PubMed]

69. Ogawa, Y.; Tsujimoto, M.; Yanoshita, R. Next-generation sequencing of protein-coding and long non-protein-coding RNAs in two types of exosomes derived from human whole saliva. Biol. Pharm. Bull. 2016, 39, 1496-1507. [CrossRef]

70. Ogawa, Y.; Kanai-Azuma, M.; Akimoto, Y.; Kawakami, H.; Yanoshita, R. Exosome-like vesicles with dipeptidyl peptidase IV in human saliva. Biol. Pharm. Bull. 2008, 31, 1059-1062. [CrossRef]

71. Langevin, S.; Kuhnell, D.; Parry, T.; Biesiada, J.; Huang, S.; Wise-Draper, T.; Casper, K.; Zhang, X.; Medvedovic, M.; Kasper, S. Comprehensive microRNA-sequencing of exosomes derived from head and neck carcinoma cells in vitro reveals common secretion profiles and potential utility as salivary bi-omarkers. Oncotarget 2017, 8, 82459-82474. Available online: https: / / pubmed.ncbi.nlm.nih.gov/29137278/ (accessed on 24 June 2021). [CrossRef] [PubMed]

72. Patel, S.; Shah, K.; Mirza, S.; Shah, K.; Rawal, R. Circulating tumor stem like cells in oral squamous cell carcinoma: An unresolved paradox. Oral Oncol. 2016, 62, 139-146. [CrossRef] [PubMed]

73. Chen, J.-Y.; Chang, Y.-C. Strategies for isolation and molecular profiling of circulating tumor cells. In Results and Problems in Cell Differentiation; Springer: New York, NY, USA, 2017; Volume 994, pp. 43-66.

74. Inhestern, J.; Oertel, K.; Stemmann, V.; Schmalenberg, H.; Dietz, A.; Rotter, N.; Veit, J.; Görner, M.; Sudhoff, H.; Junghanß, C.; et al. Prognostic role of circulating tumor cells during induction chemotherapy followed by curative surgery combined with postoperative radiotherapy in patients with locally advanced oral and oropharyngeal squamous cell cancer. PLoS ONE 2015, 10, e0132901. [CrossRef] [PubMed]

75. Ito, H.; Hatori, M.; Kinugasa, Y.; Irie, T.; Tachikawa, T.; Nagumo, M. Comparison of the expression profile of metasta-sis-associated genes between primary and circulating cancer cells in oral squamous cell carcinoma. Anti. Cancer Res. 2003, 23, 1425-1431.

76. Gröbe, A.; Blessmann, M.; Hanken, H.; Friedrich, R.E.; Schön, G.; Wikner, J.; Effenberger, K.E.; Kluwe, L.; Heiland, M.; Pantel, K.; et al. Prognostic relevance of circulating tumor cells in blood and disseminated tumor cells in bone marrow of patients with squamous cell carcinoma of the oral cavity. Clin. Cancer Res. 2014, 20, 425-433. [CrossRef]

77. Oliveira-Costa, J.P.; De Carvalho, A.F.; da Silveira, G.G.; Amaya, P.; Wu, Y.; Park, K.-J.J.; Gigliola, M.P.; Lustberg, M.; Buim, M.E.C.; Ferreira, E.; et al. Gene expression patterns through oral squamous cell carcinoma development: PD-L1 expression in primary tumor and circulating tumor cells. Oncotarget 2015, 6, 20902-20920. [CrossRef]

78. Strati, A.; Koutsodontis, G.; Papaxoinis, G.; Angelidis, I.; Zavridou, M.; Economopoulou, P.; Kotsantis, I.; Avgeris, M.; Mazel, M.; Perisanidis, C.; et al. Prognostic significance of PD-L1 expression on circulating tumor cells in patients with head and neck squamous cell carcinoma. Ann. Oncol. 2017, 28, 1923-1933. [CrossRef] 